\title{
SOCIAL MEDIA AND POLITAINMENT (Critical Discourse Analysis of President Joko Widodo's Working Visit to Sukabumi, West Java on 8 April 2018 on Twitter Joko Widodo and Prabowo Subianto Supporters)
}

\author{
Iding Rosyidin ${ }^{1}$, Renaldy Akbar ${ }^{2}$ \\ \{iding.rosyidin@uinjkt.ac.id ${ }^{1}$, renaldy.fisipuin@gmail.com ${ }^{2}$ \} \\ Universitas Islam Negeri Syarif Hidayatullah Jakarta, Indonesia ${ }^{1,2}$
}

\begin{abstract}
This study analyzes the politainment discourse of President Joko Widodo's (Jokowi) working visit to Sukabumi, West Java on April 8, 2018 on Twitter Jokowi and Prabowo supporters. The high level of public discussion on social media about President Jokowi's personal style during his visit to Sukabumi became a reference to illustrate the concept of politainment. From the analysis using the critical discourse analysis theory from Norman Fairclough model found that based on text analysis, texts written on Twitter Jokowi and Prabowo supporters mostly talked about President Jokowi's personal style and entertaining situation rather than the substance of the visit itself. Based on the analysis of discourse practices, information about the work visit was obtained from other social media (such as Youtube, Facebook, and Whatsapp) for later discussion on Twitter. Based on socio-cultural analysis, the discourse hides the practice of power to gather public sympathy at the 2019 Presidential Election.
\end{abstract}

Keywords: Politainment, President Jokowi's Work Visit, Jokowi's Supporter Twitter, Prabowo's Supporter Twitter

\section{Introduction}

This research discusses about politainment discourse in social media in a democratic context. One of the politainment phenomena is seen in the political discussion on social media about President Joko Widodo's (Jokowi) working visit to Sukabumi, West Java, which should discuss the substance of the visit, which reviewing the implementation of the Cash Intensive Work Program or PKT but what happened instead discussed the President Jokowi's personal style (such as the jacket and chopper motorcycle he ride). Social media which should have been able to strengthen democracy through critical public discourse, but on the other hand facilitates insubstansial discourse.

The substance of President Jokowi's working visit to Sukabumi on April 8, 2018 was a reviewing the implementation of the Cash-for-Work Program. This program is important to discuss because there is a critical point for labor intensive supervision. First, there are no clear technical regulations to govern the field. Second, misuse of village funds should also be watched out because the funds disbursed are not small, which is as much as 60 trillion rupiahs. 
The reason why Twitter should be analyzed to see the practice of discussion about President Jokowi's work visit to Sukabumi is because Twitter allows conversations that are not bound by social, physical, space and time constraints. Unlike Facebook which has a limited number of friends, Twitter is open without any limitation on the number of following and followers so that each account can engage in conversations through the replies, mentions, and retweets. In addition, Twitter is packaged as a medium of conversation that only provides 280 characters per chat so that interpersonal communication occurs quickly and continuously [1].

The high level of conversation related to President Jokowi's personal style during his visit to Sukabumi can be seen from the results of an Intelligence Media Management (IMM) analysis that contained that talks about President Jokowi's work visit to Sukabumi on Twitter reached 56,953 tweets. With hashtags such as \# SolidKaryaTunai2018 of 23,238 cuitans, \#JokowiMotoran of 1,923 .

The high level of conversation about President Jokowi's personal style during his visit to Sukabumi can be seen from the results of an Intelligence Media Management (IMM) on February 9, 2019, analysis that contained that talks about President Jokowi's work visit to Sukabumi on Twitter reached 56,953 tweets. The presence of social media which has been claimed to strengthen democracy, but on the other hand can facilitates insubstantial discussion, one of that practice is politainment discourse during President Jokowi's visit to Sukabumi. Discussions on social media focused on President Jokowi's personal style like the jeans jacket he wore, his metallic vans shoes, and the motorcycle chopper he rode. Not only about style, but also about the entertaining situation conversations. Starting from the three-star hotel where President Jokowi was staying, until the story of a bare-chested man who chased him while driving.

This study analyzes the discussion texts on Twitter supporters of Jokowi and Prabowo Subianto by using the critical discourse analysis method from Norman Fairclough. This method is used to see the power practices behind the discourses. Based on the problem statement, this research focused on political aspect in the discourse of President Jokowi's work visit to Sukabumi on Twitter social media. The research questions are: 1. What is the analysis of President Joko Widodo's working visit discourse to Sukabumi on Twitter Joko Widodo supporters? 2. What is the analysis of President Joko Widodo's working visit to Sukabumi on Twitter Prabowo Subianto supporters?

\section{Theoretical and Conceptual Framework}

The theory used in this study is the critical discourse analysis developed by Norman Fairclough. According to Norman Fairclough's critical discourse analysis model, discourse analysis is divided into three dimensions [2], including: text analysis, discourse practice, and socio-cultural practice (socio-cultural practice). First, text analysis is all that refers to speech, writing, graphics, and a combination or all forms of linguistic text. In text analysis, what is analyzed is the use of vocabulary, for example the use of terms and metaphors because they want to refer to certain meanings like in President Jokowi's campaign, the "blusukan symbol" was used to represent Jokowi, who was simple and close to the people. Text analysis also looks at how the words and sentences are combined to form understanding. In text analysis, this study identifies the representation of the text written on Twitter supporters of Jokowi and supporters of Prabowo regarding President Jokowi's work visit to Sukabumi. 
Second, the analysis of discourse practices is a dimension related to the process of production and consumption. The focus in the analysis of discourse practice is how the text creator takes the discourse or theme that is to be written. Text is formed through a discourse practice that will determine how the text is produced. This process is inherent to the experience, knowledge, habits, social environment, conditions, circumstances, context, and so on that exists in the text creator. In addition, this dimension also looks at how the text is distributed. It depends on the pattern and type of text and how the nature of the institution is inherent in the text. At the level of discourse practice, the writer traces how the text about President Jokowi's work visit to Sukabumi on Twitter was produced by the text creator.

Third, socio-cultural analysis is a dimension related to context outside the text. Context relating to society, or culture, and certain politics that affect the presence of the text. In this dimension, intertextual understanding has entered into where the text is formed and forms social praxis.

The second theory is social media (social media). The term social media came together with the advent of web 2.0, the new generation of the world wide web (www) that was popularized by O'Reilly Media at the web 2.0 conference in 2004. Before the web 2.0 era (before 2000 or web 1.0), only those who have programming skills or capital owners who employ programmers who can provide content (for example text, images, or videos) on the web so that the exchange of information or data is only from one person to many people (oneto-many). But after the advent of web 2.0 everyone can provide and distribute content on web 2.0 such as Blogs, Flickr, Youtube, Facebook, Instagram, etc. so that the distribution of information occurs between many people to many people (many-to-many). The content created is called user-generated content or content created from web 2.0 users. Based on this context, Andreas M. Kaplan and Micahel Hanlein define social media as "a group of internetbased applications that are built on the foundation of ideological and Web 2.0 technologies, and allow the creation and exchange of user-generated content". In line with that definition, Anthony Mayfield also understands social media as "a group of new types of online media" (Anthony Mayfield, 2008). Alan Cann uses the term social media to refer to internet services where content is produced by service users [3]. Based on these definitions it can be concluded that social media is a group of online media that facilitates users to be able to create content (for example text, photos, or videos).

The social media used to view discourse practices regarding President Jokowi's work visit to Sukabumi is Twitter. As many as $27 \%$ of internet users in Indonesia use Twitter for social networking, access to information, and conducting public conversation [4]. Although the percentage of Twitter users in Indonesia is fairly low, most of the discourse that has become a public conversation comes from Twitter.

Twitter is a social network in the online microblog category that allows its users to read and send text-based messages of up to 280 characters known as tweets. Twitter is a digital technology product that is becoming a new medium for the communication and information process of today's society [5]. What distinguishes Twitter from other social media is that Twitter has unique characteristics where users can search for specific words or phrases in the search feature that makes it easy for users to follow topics that are in the public spotlight (trending topic) on Twitter. This feature is also supported by innovations made by users by using hashtags (\#) in their tweets so that they can be grouped with similar topics. The hashtags feature on Twitter is the pioneer of social media movements using hashtags.

As a new medium, Twitter has four characteristics, including: First, digitality. A variety of content sent by users undergoing the process of digitization so that it becomes displayed on the Twitter page. Both text and photo scattered everywhere anytime. Second, interactivity. 
Twitter connects messages or tweets between users. This side of interactivity is not owned by conventional media. Third, dispersallity. There is a bias between which is the producer and consumers of information. Fourth, virtuality. Interaction between users takes place virtually which is usually conveyed via computer or mobile phone.

The concept used in this research is politainment. An explanation of politainment is needed to conceptualize the conversation of President Jokowi's work visit to Sukabumi which is dominated by discussions regarding personal style and entertaining situations, not the substance of the work visit itself. The word politainment itself comes from the words "politic" (politics) and "entertainment" (entertainment). The concept of politainment is a new type of political communication that combines politics and entertainment. In a broader sense, politianment shows the discussion of political actors, topics, and processes with nuances of entertainment. Like entertainment culture that covers the private side of celebrities, the conversation in poltainment also discusses the style, personal life, or scandal of political actors [6].

According to Jörg-Uwe Nieland, politainment includes two processes [6]: (1) political entertainment, this process occurs when the culture of entertainment exploits political topics into various entertainment formats. The entertainment industry tends to exploit the political world by highlighting politicians who have attractive personalities, prestigious figures, or political scandals with entertaining content; (2) entertaining politics, namely how political actors utilize the workings of the entertainment industry to improve their image. This happens for example when political candidates expose their personal characteristics, style and personal life to attract public discussion.

\section{Methodology}

This study uses a qualitative approach, namely research that aims to identify the nature or characteristics of a group of people, objects, or events [7]. Therefore, this study presents a detailed description of the practice of President Jokowi's work visit to Sukabumi on Twitter. Considering this research is an analysis of events on Twitter, this study takes data from two groups of Twitter accounts, namely the Joko Widodo supporting account group and Prabowo Subianto supporters. The selected accounts are the accounts that write the discussion regarding President Jokowi's work visit to Sukabumi. The account criteria that are sampled have more than 10,000 followers and have a high engagement with followers as a sign that the account is not a robot account and has a significant influence on public conversation on Twitter. This study uses two data sources, including 1) primary data, namely First, text (speech interaction, graphics, memes, caricatures, or photos) in a chat about President Jokowi's visit to Sukabumi on Twitter. Second, interviews with research subjects or account holders who contain the text, and 2) secondary data, i.e. data obtained from books, research journals, or articles on the internet. The analysis technique used in this study is Critical Discourse Analysis (CDA) analysis, which is an in-depth study that seeks to uncover activities, views, and identities based on the language used in the discourse. In the analysis of critical discourse, the language analyzed is not merely described from the linguistic aspect, but also relates it to the context. The context in question is used to uncover the practices of power that occur [8]. The critical discourse analysis model used in this study is the analysis model developed by Norman Fairclough. According to him, critical discourse analysis sees discourse as a form and social 
praxis. Discourse as social praxis is defined as a dialectical relationship between certain discourse events and the situations, institutions and social structures that shape it.

[2]:

There are three dimensions of the Fairclough model critical discourse analysis framework

1. Text analysis, i.e. all those that refer to writing, images, graphics, photographs and their combinations. In text analysis, what is analyzed is the use of vocabulary related to certain meanings. Vocabulary includes the meaning of words where one word can have many meanings according to the context. In textual analysis, this study identifies the representation of the text written on Twitter supporters of Jokowi and supporters of Prabowo regarding President Jokowi's work visit to Sukabumi.

2. Analysis of discourse practice, an analysis at the level of discourse practice tracing how the text about President Jokowi's work visit to Sukabumi on Twitter was produced by the text creator. Analysis of the practice of this discourse was obtained from interviews with text makers both from Twitter accounts supporting Jokowi and supporters of Prabowo.

3. Socio-cultural analysis (sociocultural), which is an intertextual understanding to analyze social events in which it appears that the text is formed and forms social praxis. This dimension looks at how the social context outside the text influences the discourse within the text including the situational, institutional, and social dimensions. The socio-cultural analysis in this study traces the context that influenced the text about the president's work visit to Sukabumi by Twitter supporters of Jokowi and supporters of Prabowo.

\section{Analysis and Discussion}

Based on the analysis of critical discourse, the subject of the two camps showed a discussion that had an element of politainment because it was related to President Jokowi's driving and dress style. In Twitter supporters of Jokowi, the discourse discussed is about a chopper motor, a shirtless man who approached Jokowi during a touring, the Dilan 1990 film, and the jacket worn by Jokowi. The conversation certainly aims to improve President Jokowi's positive image to the public in relation to the 2019 Presidential Election (see Table 1). Instead of attacking Jokowi's camp with substantial discussion, Prabowo's supporters were also caught up in the conversation with elements of politainment. Instead, they discussed the traffic violations, the cost of touring, and the price of Jokowi's jacket, not criticizing the policies of the visit. This was done to build President Jokowi's negative image but not based on substantial criticism. 
Tabel 1. Comparison of Discourse Analysis

\begin{tabular}{cccc}
\hline \multicolumn{4}{c}{ Text Analysis } \\
\hline Jokowi's Supporters & Representation & Prabject & Representation \\
\hline Subject & $\begin{array}{c}\text { The President is friendly } \\
\text { and without a barrier to } \\
\text { the people }\end{array}$ & $\begin{array}{c}\text { Jokowi's motorcycle } \\
\text { doesn't use a fender }\end{array}$ & $\begin{array}{c}\text { The President did not } \\
\text { set a good example }\end{array}$ \\
\hline Dilan 1990 film & $\begin{array}{c}\text { The President has a } \\
\text { young soul }\end{array}$ & $\begin{array}{c}\text { The price of Jokowi's } \\
\text { jacket is expensive }\end{array}$ & $\begin{array}{c}\text { Jokowi's popular image } \\
\text { is gone }\end{array}$ \\
\hline Jokowi's jacket & $\begin{array}{c}\text { Have a nationalism spirit } \\
\text { because of using } \\
\text { local products }\end{array}$ & $\begin{array}{c}\text { Jokowi's touring fee is } \\
\text { expensive }\end{array}$ & Wasteful \\
\hline Chopper Motorcycle & $\begin{array}{c}\text { Masculine side on } \\
\text { Jokowi }\end{array}$ & & \\
\hline
\end{tabular}

\section{Discourse Practice Analysis}

Both Jokowi and Prabowo supporters get information about President Jokowi's working visit to Sukabumi from other social media (such as Youtube, Facebook, and Whatsapp) for later discussion at Twitter

\begin{tabular}{cccc}
\hline \multicolumn{4}{c}{ Socio-cultural Analysis } \\
\hline Supporters & Situasional & Institusional & Sosial \\
\hline \multirow{2}{*}{ Jokowi } & & & $\begin{array}{c}\text { Improve Jokowi's } \\
\text { positive image }\end{array}$ \\
\cline { 3 - 4 } Prabowo & $\begin{array}{c}\text { Related to the 2019 } \\
\text { Presidential Election }\end{array}$ & $\begin{array}{c}\text { Not part of the success } \\
\text { team }\end{array}$ & $\begin{array}{c}\text { Building Jokowi's } \\
\text { negative image }\end{array}$ \\
\hline
\end{tabular}

The discussion of politainment in the two camps took place inseparably from the role of other media. Based on the analysis of discourse practices by the author, the two camps received information about President Jokowi's visit to Sukabumi through online media, Youtube, and Whatsapp. The reason they use Twitter is because social media is very effective at creating public delibration. This is as stated by Julian Ausserhofer and Axel Maireder about the use of Twitter in politics that Twitter allows public discussion and has the ability to link to other media content so that Twitter is an integral part of the networked public sphere that appears with mass media [1].

\section{Conclusion}

Social media as a new public space that should be able to open more open and critical discussion spaces [9], in fact, on the other hand actually facilitates the practice of discussion that is not substantial that runs through the practice of politainment. The discourse regarding President Jokowi's work visit to Sukabumi on Twitter Jokowi's supporters and Prabowo's supporters represented the political discourse because of the conversation about the president's personal style and entertaining situation rather than the substance of the visit itself. 
Emphasis on personal style in political discussion can obscure substantive issues and policies. Displaying politicians into the culture of entertainment can position the public as fans and politicians as celebrities so that citizens as fans are more interested in seeing personal characteristics, private activities, style or appearance like popular celebrities rather than policies implemented by politicians. In addition, news or conversation that presents politics through entertainment formats can create a false picture of political reality rather than advance citizens' political knowledge.

\section{References}

[1] J. Ausserhofer and A. Maireder, "National Politics on Twitter: Structures and Topics of a Networked Public Sphere," Information, Commun. Soc. J., vol. 3, no. 13, 2013.

[2] Haryatmoko, Critical Discourse Analysis: Landasan Teori, Metodologi, dan Penerapan. Jakarta: Raja Grafindo Persada, 2017.

[3] A. Cann, "Social Media: A Guide for Researchers," 2011. [Online]. Available: www.rin.ac.uk.

[4] S. Kemp, "Digital in 2018: Essential Insight IntoInternet, Social Media, Mobile, Ecommerce Use Around the World," 2018. [Online]. Available: www.wearesocial.com.

[5] F. Andriadi, Demokrasi di Tangan Netizen. Jakarta: RMBooks, 2016.

[6] J. Nieland, "Politainment," he International Encyclopedia of Communication. 2008.

[7] U. Silalahi, Metode Penelitian Sosial. Bandung: Refika Aditama, 2010.

[8] A. Badara, Analisis Wacana: Teori, Metode, dan Penerapannya pada Wacana Media. Jakarta: Kencana, 2012.

[9] S. Simarmata, "Media Baru, Ruang Publik Baru, dan Transformasi Komunikasi Politik di Indonesia," J. Ilmu Komun., vol. 3, no. 2, 2014. 